\title{
ARRANJO PARA CORO INFANTIL: ALGUNS RECORTES E FERRAMENTAS
}

\author{
Arrangement for children's choir: some clippings and \\ tools
}

\author{
DAISY FRAGOSO \\ Universidade de São Paulo \\ daisy.fragoso@usp.br
}

\begin{abstract}
Resumo: O presente texto apresenta algumas reflexões acerca da criação de arranjos para coros infantis. Considera-se aqui a prática coral como um meio de educação musical, por isso, partindo da necessidade de que regentes se reconheçam educadores, estes são convidados a repensarem suas práticas nas quais se inclui a criação por meio da elaboração de arranjos musicais para estes grupos. Para tal, são apresentados exemplos da literatura musical coral nacional e internacional (e ocidental) que possam servir como ferramentas por meio das quais regentes, educadores musicais e demais músicos criem seus arranjos.
\end{abstract}

Palavras-chave: Coral infantil. Arranjo. Regente-educador.

Abstract: This text presents some reflections on the creation of children's choir arrangements. Choir practice is herein considered a means of musical education; therefore, for choir directors to recognize themselves as educators, they are invited to rethink their practices, including the creation process through the elaboration of musical arrangements for children's choirs. For this purpose, examples of national and international (and occidental) choral music literature, which can serve as tools for choir directors, musical educators, and other musicians to create their arrangements, are presented.

Keywords: Children's choir. Arrangement. Director-educator. 


\section{INTRODUÇÃO}

A escolha para escrever sobre este tema tem origem nas reflexões que, enquanto educadora musical que atua também como regente de coro infantil, foram colecionadas ao longo do tempo. Também partem de observações inquietas geradas na necessidade, às vezes imposta pelo trabalho de regente de coro infantil, às vezes provocada por mim mesma como uma resposta aos impetos criativos, de escrever arranjos corais para os grupos infantis que conduzia.

Derivaram desse tema principal - arranjo para coro infantil - várias linhas, gerando tópicos outros. Frutos do pensamento rizomático, isto é, de um pensamento guiado por linhas diversas e múltiplas que se conectam, que se emaranham (Brito, 2007, p. 265), estas relações se baseiam em minhas experiências musicais e profissionais e são marcadas, por isso, pela singularidade do meu trajeto (Santos, 2000, p. 71 e 72). Isso quer dizer que, ao longo deste texto, as escolhas feitas sobre os pontos a serem discutidos (e que foram gerados por esses rizomas) têm a ver com o que entendo que seja o papel do canto coral, o que, por sua vez, fez-se e refaz-se em função dos caminhos que percorri como educadora musical.

\section{O REGENTE-EDUCADOR-CRIADOR}

Entende-se aqui o canto coral, ou prática coral, como uma das ferramentas possiveis de musicalização, ou seja, como um meio de educação musical. Essa concepção altera, consequentemente, tanto o discurso em relação ao fazer musical com grupos corais quanto a própria prática nesses contextos. Nesse sentido, é relevante ressaltar que os pontos destacados ao longo do texto serão influenciados por essa ótica, de modo que o regente passa a ser considerado também educador musical, assim também entendido por Gaborim-Moreira (2015), Braga e Tourinho (2013), Robinson e Winold (1976), Pfautsch (1988) e outros.

O fato de atribuir ao regente tal papel acaba rearranjando a sua prática, humanizando-a, aos moldes de Freire (1996), no sentido de que a metodologia de trabalho, os objetivos a serem alcançados, os critérios estipulados para ingresso no coro, a escolha do repertório etc.responderão a essa orientação. Por exemplo, pode ser que o regente que não se reconhece educador deseje que o resultado do trabalho seja unicamente o bom desempenho do coro no concerto onde se apresentará o repertório trabalhado; já o regente-educador estará preocupado também com os processos musicais e sociais vivenciados pelo grupo antes de alguma apresentação. Pode ser que o primeiro esteja focado em cumprir um programa que não dialoga social, cultural e musicalmente com os coralistas, ao passo que o segundo está atento à possibilidade de aproveitar o contexto social, cultural e musical do grupo para desenvolver habilidades diversas que podem ser tanto musicais quanto 
humanas. O regente-educador, antes de tudo, coloca-se reflexiva e criticamente diante sua prática - que é pedagógica, não somente musical -, permitindo-se (re)inventá-la em um processo constante de construção e criação.

Por esta razão é que, em um contexto de educação musical, vê-se no regente mais que um educador musical: vê-se a necessidade de um regenteeducador que se reconheça autônomo o suficiente para ser um educadorcriador, um regente-educador-criador. O regente-educador-criador elabora a sua própria metodologia, constrói seu repertório junto com seu grupo, elabora (sozinho e/ou com seus coralistas) os arranjos de canções que se deseja cantar, compõe; e sobre a criação de arranjos é que as próximas linhas discorrerão.

\section{O REPERTÓRIO PARA CORAIS INFANTIS}

Em seus trabalhos, Leal (2005), Utsunomiya (2011) e Gaborim-Moreira (2015) apontam a dificuldade que os regentes brasileiros têm de encontrar material, repertório para coros infantis. Leal (2005, p. 34), por exemplo, aponta a raridade em relação à composição específica para coro infantil de boa qualidade e a divulgação deficiente daquelas que existem. GaborimMoreira, por sua vez, levanta mais alguns fatores que colaboram para este cenário, como

[...] a escassez de discussões na área; a inexistência de politicas públicas efetivas para a educação musical; a falta de investimento à pesquisa e à capacitação técnico-pedagógica dos regentes; a insuficiência de eventos voltados especificamente ao coro infantojuvenil (como oficinas, congressos, workshops, simpósios, festivais) e o atual desinteresse de editoras em publicações dessa natureza. A pesquisa e o estudo do repertório musical de diversas épocas e estilos, bem como a elaboração de arranjos e novas composições, constituem grandes investimentos (de tempo e de dinheiro); porém, esses investimentos, aplicados a ações concretas e efetivas, com certeza, trariam saldos positivos para a área coral como um todo (Gaborim-Moreira, 2015, p. $38)$.

Já Utsunomiya (2011) atribui a escassez de material não à falta de arranjos e composições produzidos nacionalmente, mas à forma reduzida com que se publicam estas partituras nas editoras brasileiras e à forma como estas publicações são transmitidas entre os pares:

[...] A publicação de partituras publicadas por meio de editoras tradicionais [...] tem sido realizada de forma reduzida, [e] cada vez mais a produção e distribuição desse tipo de material é feita pelos próprios autores, sem intermediação de casas publicadoras. Isso ocorre devido à facilidade proporcionada pelos novos meios de comunicação e 
informação, que facilitam a reprodução de partituras em formato de arquivos digitais para leitura e impressão [...]. Uma outra parte das obras que circulam no Brasil é representada por aquelas que são editadas fora do país, o que dificulta a sua aquisição. Os altos custos para publicação tradicional, a pouca saída nas vendas de materiais editados e o hábito de não se comprar partituras editadas têm colaborado para a consolidação dessa prática de compartilhamento informal de partituras produzidas pelos regentes, arranjadores e compositores brasileiros (Utsunomiya, 2011, p. 43).

A fim de tentar resolver a dificuldade apontada, Gaborim-Moreira (2015) e Leal (2005), por exemplo, indicam nos relatos dos regentes entrevistados nos respectivos trabalhos de pesquisa a atuação destes como arranjadores, e mesmo como compositores de peças originais. Seria de grande proveito para a área coral no Brasil, inclusive, se esses arranjos e composições fossem organizados e publicados ${ }^{1}$.

A tentativa, portanto, do presente texto é apresentar algumas ferramentas que possam ajudar o regente-educador-criador e outros mais que estejam - ou não - envolvidos com o canto coral na tarefa de escrever para coro infantil, seja para acudir a falta de arranjos escritos para essa modalidade, seja para responder às necessidades do grupo que se dirige (ou as duas coisas). Ainda que a dificuldade de encontrar material adequado, no Brasil, para coro infantil, possa ser um dos motivos para a criação de arranjos, salienta-se aqui que pensar e criar um repertório sensivel ao contexto em que o coral está inserido é a essência de uma prática que considera o regente como educador musical.

A fim de exemplificar o que foi dito, permitam-me escrever em primeira pessoa. É possível que eu escreva um arranjo que vá ser executado por diferentes grupos corais, e este soará adequadamente. No entanto, quando escrevo um arranjo para o meu coro, deparo-me com a obrigação (ou necessidade) de conciliar os aspectos estéticos e os pedagógicos específicos ao grupo. Em outras palavras, conhecendo meu coro, quais são as suas dificuldades musicais, o que seus cantores são capazes de fazer, quais são os desafios que pretendo propor e superar, escrevo considerando também estas questões, e não somente o resultado estético. Isso não quer dizer que outros coros não possam utilizar arranjos escritos por outras pessoas que não o próprio regente, ou que só o regente é quem deve escrever os arranjos para o seu próprio coral, dispensando-se o trabalho de compositores e arranjadores que não são os regentes do coro em questão; o que se pretende dizer é que o regente pode ser um arranjador e que, articulando-se as intenções estéticas e as pedagógicas, há grande chance de a obra soar bem e de proporcionar

\footnotetext{
${ }_{1}^{1}$ Ainda que seja uma especulação, parece relevante dizer que pode ser que a falta de interesse em publicar este tipo de material consista em sua pouca rentabilidade, considerando o costume de parte de nossos regentes de fazerem cópias não autorizadas dos trabalhos alheios. No entanto, é possível também (e aqui se faz outra especulação) que esta prática aconteça justamente pela dificuldade de encontrar materiais dessa natureza.
} 
satisfação e crescimento musicais ao grupo. É frustrante e desmotivador quando se despende tanta energia em uma peça que não foi bem-sucedida, por mais bonita que ela seja; e o é tanto para o regente quanto para os coralistas. Quando se escreve, porém, considerando o grupo para o qual se está escrevendo, os desafios e o que já se executa bem podem ser dosados em medida ideal, e o resultado musical pode ser compensador, individual e coletivamente. Este equilíbrio é o que está sendo chamando aqui de intenções pedagógicas.

O mesmo critério é proposto quando se está selecionando peças já arranjadas para o coro: é preciso encontrar nesses arranjos o equilíbrio entre os desafios e as competências superadas e a articulação disso com os elementos estéticos. Esse ponto de equilíbrio é próprio de cada grupo e ao regente cabe encontrá-lo. Já o que se pretende esteticamente é a combinação entre o respeito pelas ideias de música ${ }^{2}$ dos coralistas e a valorização delas, e as ideias de música que o regente-educador tem para lançar à mesa. Sobre o primeiro, o que está sendo referido nada mais é que a aplicação na educação musical - e no canto coral, sob essa perspectiva - do que Freire sugere ao dizer que ensinar exige respeito aos saberes dos educandos (1996, p. 30-31).

$\mathrm{Na}$ educação musical, estes saberes contemplam também os saberes musicais, de modo que, quando é sugerido que se respeite os saberes dos educandos, pode-se entender, em nossa área, que sejam respeitados valorizados e incluídos no repertório (ou currículo) - também os saberes musicais dos nossos alunos, das nossas alunas, cantores e cantoras. E isto não quer dizer simplesmente considerar o conhecimento prévio dos alunos, ou partir do que o aluno já sabe para seguir o trabalho (o que, na prática, é a exclusão de tais saberes); antes, sim, significa incluí-los no currículo para que, utilizando o que o aluno conhece, seja feito o trabalho. Ou ainda, nas palavras de Freire, é "estabelecer uma 'intimidade' entre os saberes curriculares fundamentais aos alunos e a experiência social que eles têm como indivíduos" (1996, p. 30). E aqui, talvez, a maior dificuldade do regenteeducador seja reconhecer que "a música contém muitas músicas" (Brito, 2007, p. 33) e que todas essas músicas são igualmente válidas.

Assim, deslocando a ideia freiriana (Freire, 1996, p. 30) para a educação musical $^{3}$ e, mais especificamente, para o canto coral, caberia, a título de ilustração, o questionamento parafraseado: se os seus alunos fazem parte das classes populares, por exemplo, por que não aproveitar a experiência musical e as ideias de música deles, elaboradas no contexto onde vivem, que, em geral,

\footnotetext{
2 Brito $(2007,2015)$ utiliza o termo "ideias de música” fazendo referência às diversas concepções acerca do que é música.

${ }^{3}$ As relações entre a educação musical e as ideias de Paulo Freire para a educação são amplamente discutidas em trabalhos como os de Joly e Severino (2016), Joly e Joly (2011) e Targas e Joly (2009), para citar alguns poucos.
} 
são áreas da cidade desconsideradas pelo poder público, para discutir, por exemplo, a violência contra a população das periferias ${ }^{4}$ ?

Contudo, foi levantado anteriormente que era necessária a combinação entre os saberes dos educandos (que, neste caso, são nossos cantores), suas ideias de música e aquelas do educador, isto é, do regente. Se o ponto levantado anteriormente pretende considerar o aluno como sujeito ativo em qualquer processo de educação, este agora pretende que sejam ampliados seus saberes musicais e suas ideias de música. Quando o regente apresenta ao coralista outras ideias de música, outras possibilidades sonoras (experimentadas no repertório trabalhado), são provocados movimentos entre as ideias de música dos cantores e aquelas do regente, rearranjando as impressões acerca dessas ideias, o que, por sua vez, amplia não somente o repertório, mas o conceito de música (Fragoso, 2015, p. 104).

Assumindo, então, o papel de educador musical que o regente desempenha, é essencial que ele atue como provocador e mediador desse movimento entre as diversas ideias de música, "[...] articulando as ideias de música trazidas pelos alunos e interferindo no fluxo dessas ideias [...]" (Fragoso, 2015, p. 75). Este argumento, assim, é o que justifica a relevância de desenvolver com o grupo um repertório de estilo, gênero e períodos variados e de culturas diversas, ou seja, que contemple, na medida do possivel, muitas ideias de música.

\section{CRIANDO, ARRANJANDO...}

Considerando essa discussão, o primeiro passo dado pelo arranjador (que pode ser o regente ou qualquer outro músico) é, então, escolher a música que se pretende arranjar. Feita a escolha, o momento seguinte consiste no estudo do estilo ou gênero a que a canção escolhida pertence ou no qual se deseja transformar. Por exemplo, se a música a ser arranjada é um jazz, ou se é pretendido que seja um jazz, é preciso que o arranjador se dedique ao estudo desta forma de fazer música, para que o acompanhamento e/ou as vozes respondam a esse formato, como feito no arranjo abaixo. Atente para a harmonia e para o ritmo criados para o piano e para as vozes:

\footnotetext{
${ }^{4}$ Texto original no qual se baseou a paráfrase: “Por que não aproveitar a experiência que têm os alunos de viver em áreas da cidade descuidadas pelo poder público para discutir, por exemplo, a poluição dos riachos e dos córregos e os baixos níveis de bem-estar das populações, os lixões e os riscos que oferecem à saúde das gentes? Por que não há lixões no coração dos bairros ricos e mesmo puramente remediados dos centros urbanos?" (Freire, 1996, p. 30).
} 

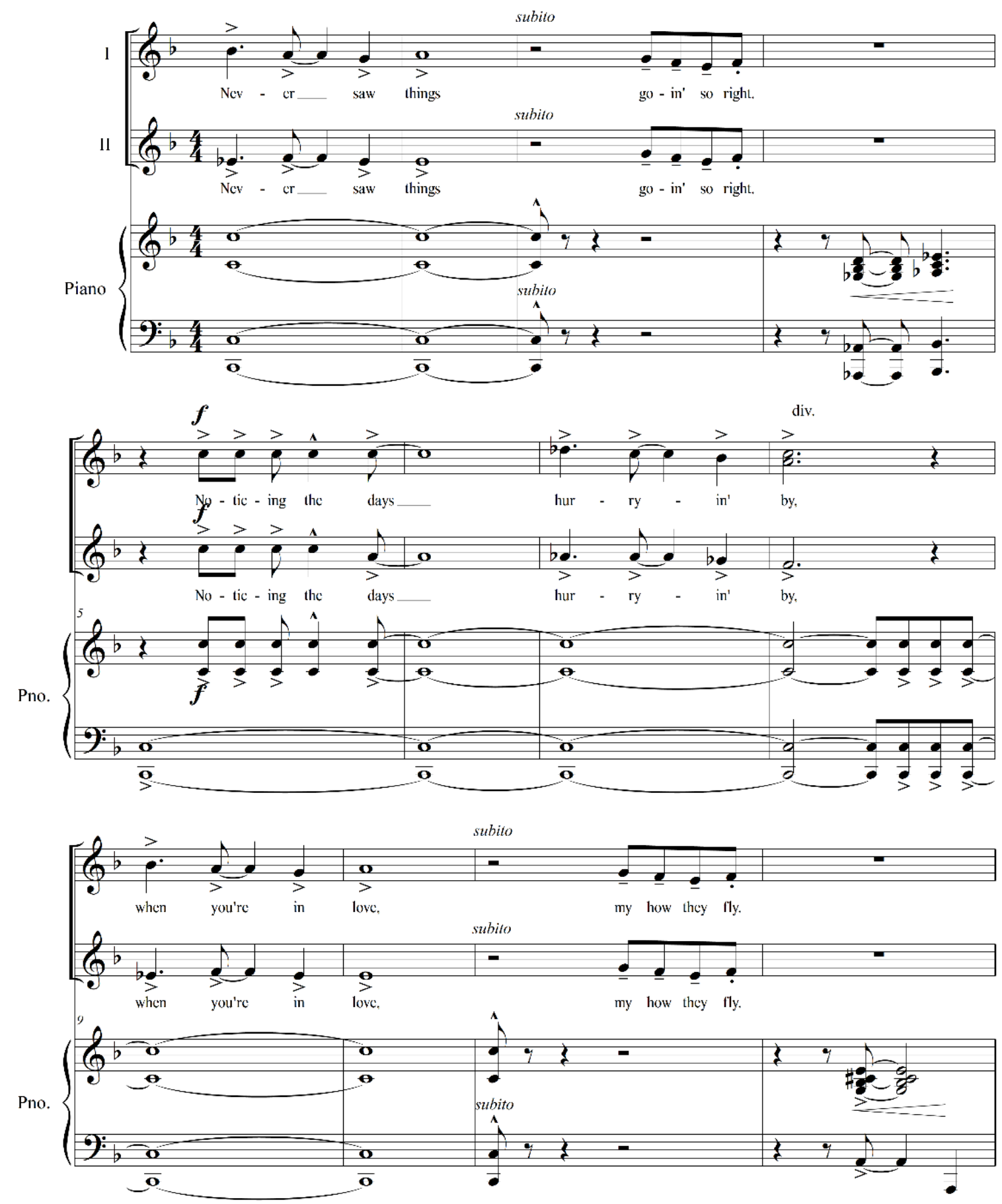

Figura 1: Trecho extraído do arranjo da canção "Blue skies" (Emerson, 2001).

Já no exemplo abaixo, a célula ritmica básica do samba é reproduzida no acompanhamento ao piano, enquanto são feitas algumas insinuações melódicas desse gênero no trecho de pergunta e resposta assinalado: 

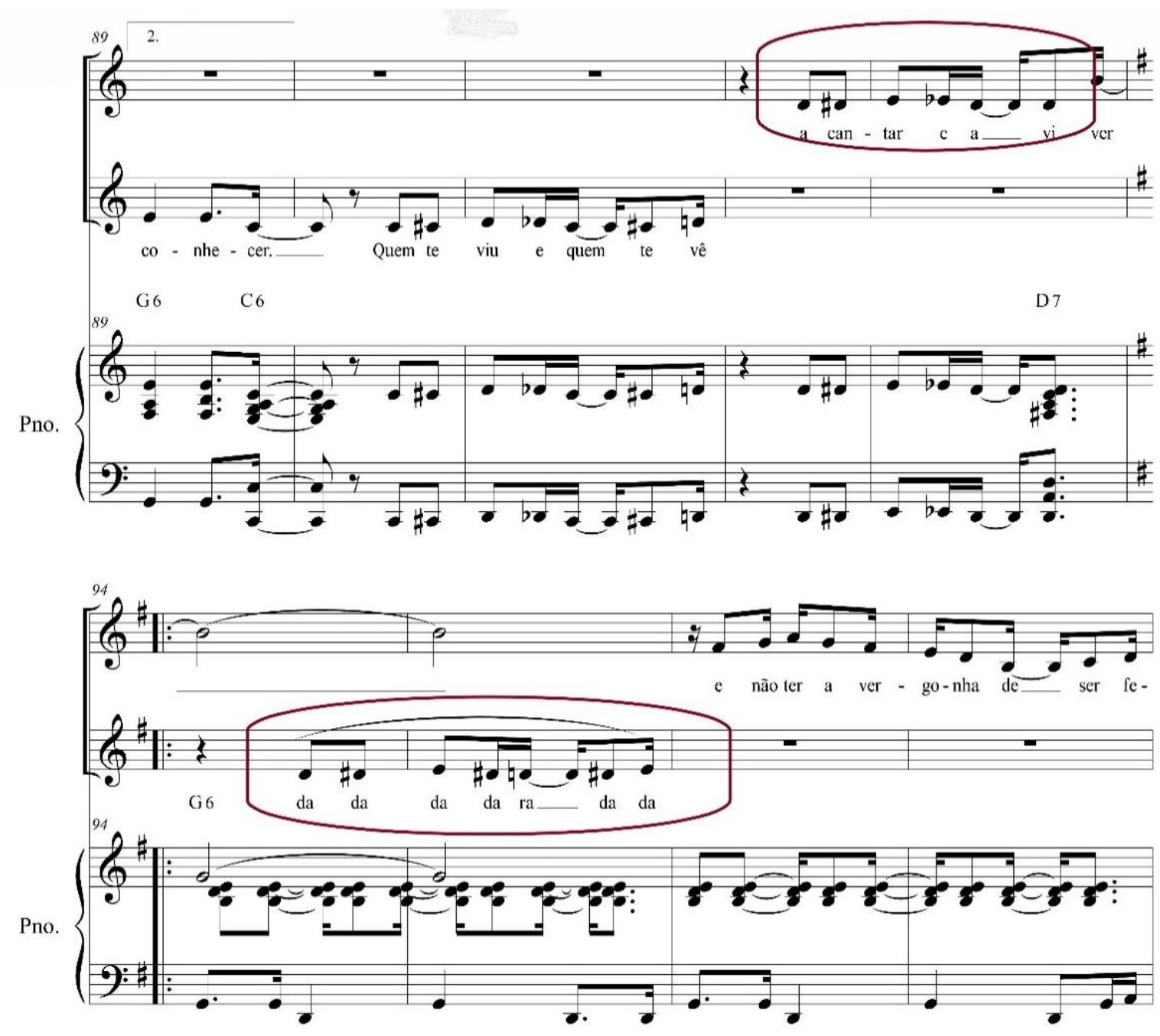

Figura 2: Trecho de "Mandaram me chamar", arranjado por Daisy Fragoso (2017), para a $13^{a}$ edição do Gran Finale - Festival Nacional de Corais Infantis e Jovens. Arranjo não publicado.

Enfatiza-se a relevância do estudo do gênero ou estilo da música a ser arranjada para que se evite a estereotipização dessas formas, principalmente quando o arranjador se envolver com o trabalho de canções de alguma cultura distinta à dele. A dedicação ao estilo que se pretende arranjar deve incluir humildade ao reconhecer que há ideias de músicas que não conseguimos passar para o papel, porque sequer as compreendemos, já que não fazemos parte do contexto ao qual a canção original pertence. Assim, o respeito pela música que se pretende arranjar é uma postura a ser reivindicada, tanto para que não a estereotipe quanto para que não a desfigure, pois esta música - e qualquer outra - falará sempre de alguém, de um povo, de uma sociedade, de um momento que alguém ou algum povo viveu. Em outras palavras, as ideias de música pertencem sempre a alguém, a um povo, a uma sociedade, e essas situações e pessoas, refletidas nessas músicas, precisam ser consideradas, respeitadas e preservadas no arranjo, até mesmo quando se pretende modificar o estilo da música original. Para que isto seja conhecido do 
arranjador, portanto, é preciso estudo e dedicação de sua parte sobre a obra que se pretende escrever.

Além de estar a par do contexto cultural e social ao qual a música a ser arranjada pertence, é preciso que o arranjador domine alguns conhecimentos técnicos pertinentes à formação ${ }^{5}$ do grupo para o qual escreverá. O primeiro deles, neste caso, é a tessitura e a extensão da voz infantil6.

A extensão vocal é, de acordo com Gaborim-Moreira, "o conjunto de alturas que podem ser emitidas por uma pessoa, desde a mínima até a máxima frequência; em outras palavras, é o conjunto total de notas que uma pessoa consegue cantar, da mais grave à mais aguda" (2015, p. 246). Para a mesma pesquisadora, é muito difícil estabelecer os limites da extensão vocal infantil, pois estes estão relacionados a características biológicas, psicológicas e culturais (Gaborim-Moreira, 2015, p. 246). Além disso, as notas estabelecidas pelos limites de uma extensão vocal nem sempre são possiveis de serem executadas pelo cantor enquanto canta (Boechat; Silveira, 2017, p. 102). Dessa forma, há pesquisadores e professores, ainda de acordo com Boechat e Silveira (2017), que preferem trabalhar com a ideia de extensão limite oposta à extensão confortável, de modo que esta última se refere à extensão que o cantor consegue executar, na hora do canto, sem desconfortos, já que não envolve os extremos de sua extensão vocal. Pode-se dizer, no entanto, que essa extensão confortável é também o que se chama de tessitura. Gainza (1964, p. 116), por exemplo, define tessitura como a região confortável da extensão vocal.

Em seu trabalho de pesquisa, Hedden (2012) investigou os resultados dos estudos dedicados à voz infantil produzidos nos Estados Unidos nos últimos 25 anos anteriores ao seu estudo. Dentre os achados, a pesquisadora relata que, nas pesquisas desenvolvidas por Kim (2000), as crianças em idade pré-escolar possuem uma extensão vocal que vai do Dó3 ao Dó4; as crianças em fase primária ${ }^{7}$ são capazes de cantar notas que vão do Sol2 ao Mi4. Já nos trabalhos de Moore (1991), constatou-se que a extensão vocal de crianças de 8 a 11 anos compreendia, aproximadamente, o intervalo do Sol2 ao Sol4.

A utilidade desses dados para o arranjador é conhecer e dominar o material para o qual vai escrever. No entanto, é preciso considerar que, ainda que esta seja a extensão possível da voz infantil (possivel, porque esta extensão varia de indivíduo para indivíduo, a depender de seu sexo, de sua idade, do contexto cultural em que foi criado ou está inserido), não é razoável escrever uma canção que contemple seus limites, justamente porque trará desconforto ao cantor, já que sua tessitura, isto é, sua região de conforto, não envolve esses limites.

\footnotetext{
${ }^{5}$ A palavra "formação", neste contexto, refere-se à formação coral: se coro infantil, se coro infantojuvenil, se coro adulto etc.

${ }^{6}$ Quando são feitas referências à voz infantil, nesse trabalho, faz-se menção ao grupo de crianças que vai desde a idade pré-escolar (4, 5 anos) até a puberdade, conforme a definição de Hedden (2012, p. 57).

7 Correspondente à fase escolar do ensino fundamental 1 brasileiro.
} 
Sobre a tessitura para voz infantil, Willians (2013, p. 99 apud Boechat; Silveira, 2017, p. 103) as divide da seguinte forma: do Dó3 ao Dó4, para crianças de 3 a 5 anos; do Sib2 ao Mi4, para crianças de 6 a 9 anos; e do Lá2 ao Sol4, para crianças de 10 a 13 anos. A mudança da "voz de peito" para a "voz de cabeça" acontece por volta do Lá3 (Boechat; Silveira, 2017, p. 104; Gaborim-Moreira, 2015, p. 255), de modo que o registro grave é o que comporta a região que descende do Sol3 até a nota mais grave contemplada na extensão vocal infantil; e o registro agudo é o que se inicia em Láb3, Lá3 e segue ascendentemente até o Sol4. Baseando-se em um modelo de Wurgler (1990 apud Gaborim-Moreira, 2015, p. 255), Gaborim-Moreira ainda inclui uma região de passagem, que fica entre o Ré3 e o Lá3. Assim, a "voz de cabeça" é aquela que corresponde aos registros agudos, e a "voz de peito" aos registros graves.

Vale dizer que, em se tratando da voz infantil, não há divisões entre vozes femininas e vozes masculinas, pois não há grandes diferenças entre a voz das meninas e a voz dos meninos até a puberdade (Carnassale, 1995, p. 68; Gaborim-Moreira, 2015, p. 257). Sendo assim, tratamos as vozes infantis, independentemente do sexo, como vozes iguais. Isso quer dizer que tanto meninas quanto meninos cantam na região grave e na região aguda; tanto meninas quanto meninos cantam utilizando a "voz de peito" ou a "voz de cabeça". Tanto é que o ideal, em um coro infantil, é que haja o mesmo número de cantores em cada voz. Há regentes que preferem classificar a divisão de vozes em "primeira voz" e "segunda voz"; outros dão preferência à classificação "soprano" e "contralto". Gaborim-Moreira (2015, p. 386) diz que a primeira alternativa tende a criar uma hierarquia no canto coral, levando os cantores a pensar que a "primeira voz" é melhor que a "segunda voz".

No entanto, em se tratando de vozes iguais, pode acontecer de a "segunda voz" cantar trechos mais agudos que a "primeira voz" durante a divisão de vozes, e isso pode causar um equívoco em relação ao que se entende por soprano e contralto, já que os sopranos detêm as regiões agudas, e os contraltos, as graves. Ou seja, considerando a igualdade das vozes, em um trecho com divisi, pode ser que a "segunda voz" esteja cantando algo na região aguda, e isto não acontece com contraltos, que cantam, predominantemente, na região grave; e o inverso pode acontecer com a "primeira voz". Enquanto em uma formação coral $\mathrm{SATB}^{8}$ não é aconselhado, nos manuais de harmonia, que sejam feitas inversões de vozes, isto é, que uma voz mais grave cante, ao mesmo tempo, algo mais agudo que o seu respectivo naipe mais agudo, nos coros infantis, em que a formação é de vozes iguais, não é raro que aconteçam tais inversões (ou "cruzamento de vozes"), como indicam os exemplos abaixo (Figuras 3, 4 e 5). Desse modo, a inversão de vozes, na composição ou criação de arranjos para coro infantil, não é algo a ser evitado a todo custo. Tanto é que, em uma formação para coro a vozes iguais (como é o caso das vozes

${ }^{8}$ Classificação para corais adultos com sopranos (S), contraltos (A), tenores (T) e baixos (B). 
infantis) as inversões de vozes acontecem natural e frequentemente nas formas canônicas e nos quodlibet.

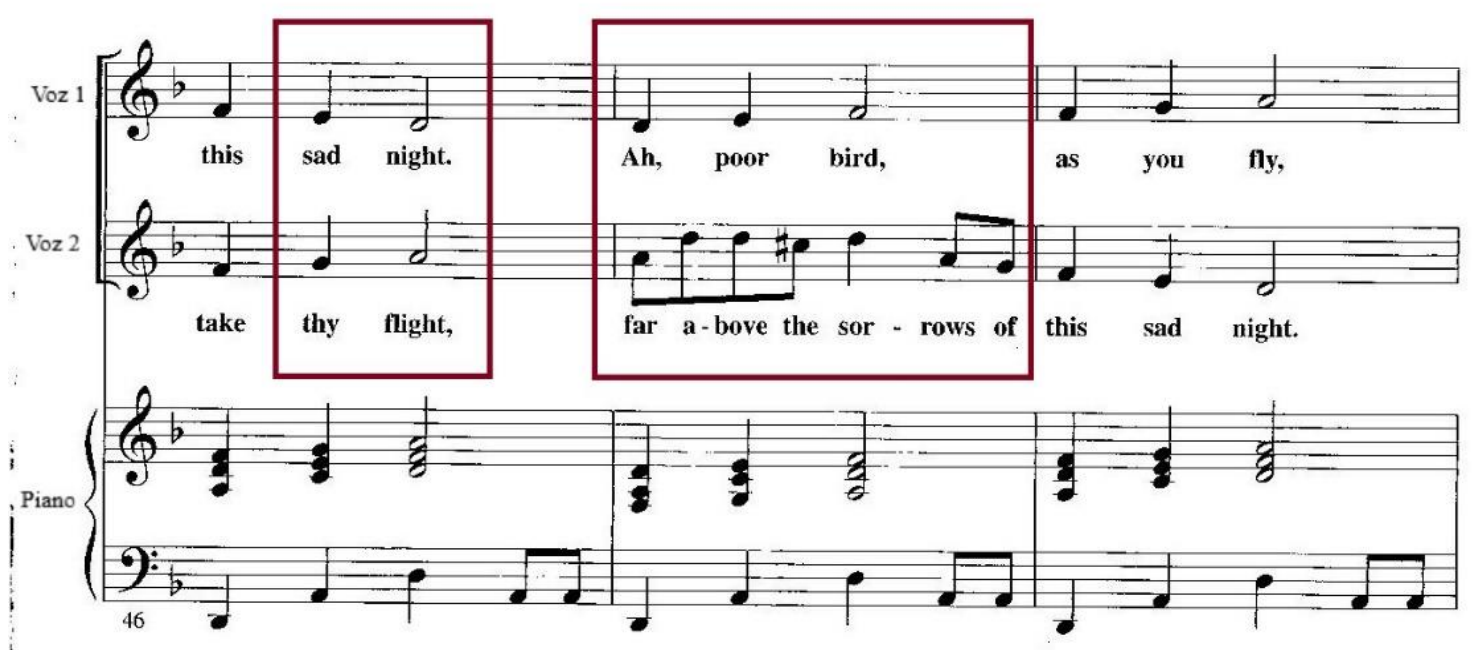

Figura 3: Trecho extraído da canção tradicional inglesa "Ah, poor bird" (Cooper, 2009).

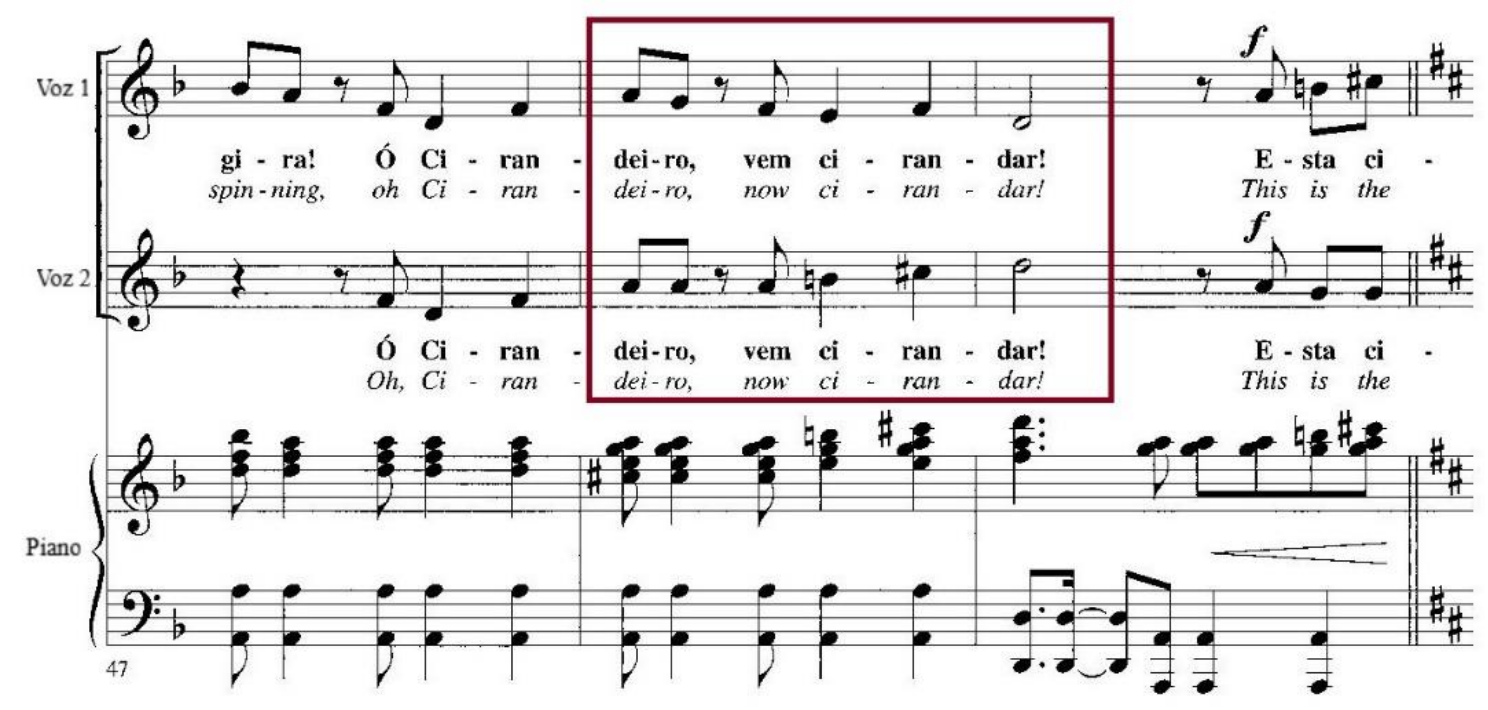

Figura 4: Trecho extraído da canção tradicional brasileira "Cirandeiro" (Green, 2005). 


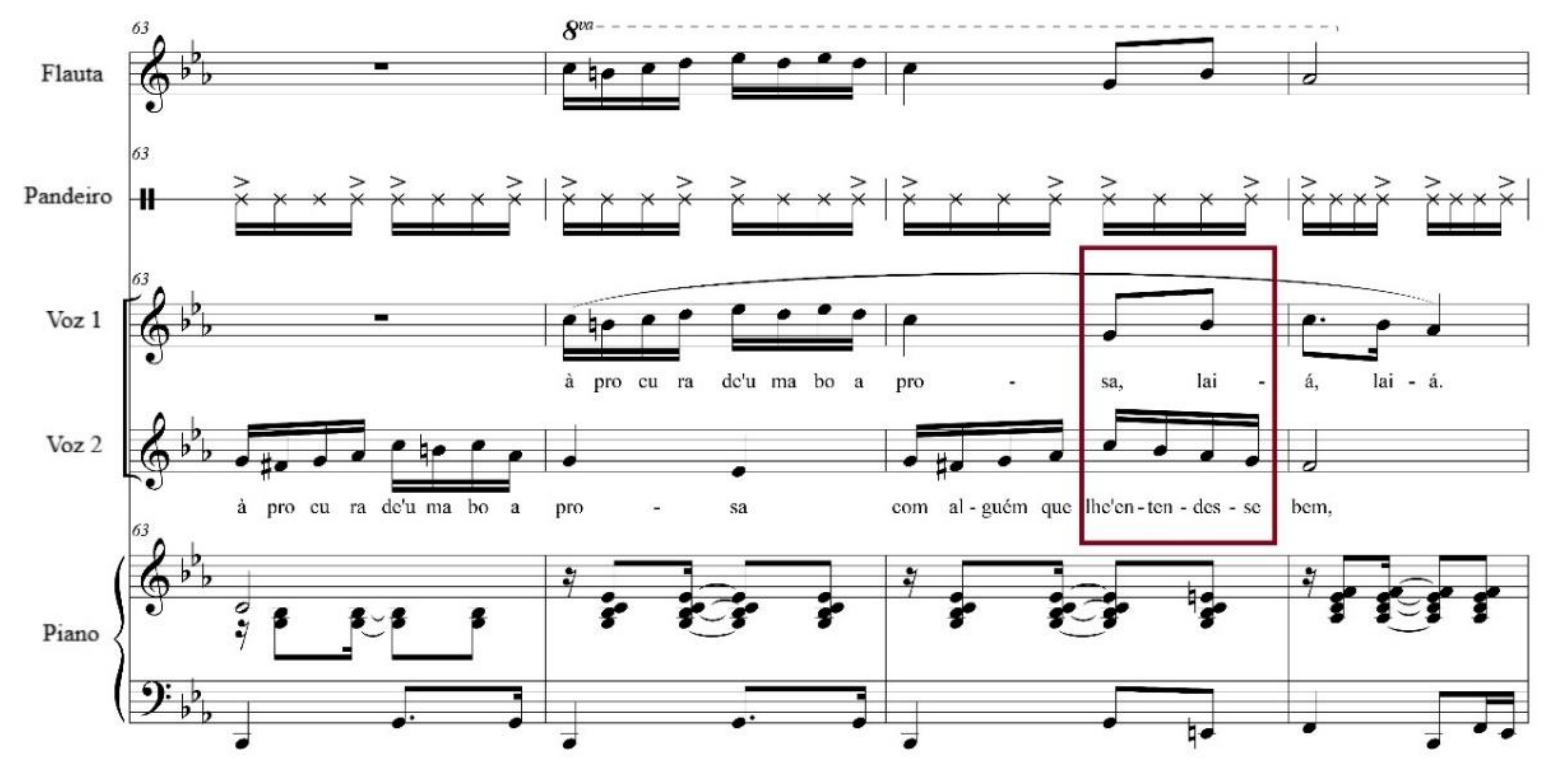

Figura 5: Trecho extraído da canção "De prosa com o passarim" (Fragoso, 2017).

Os divisi, ou a divisão de vozes, podem e devem ser explorados nos arranjos para coro infantil. Zoltán Kodály, importante educador musical da primeira geração dos métodos ativos e um dos principais entusiastas da educação musical por meio da voz (e, por isso, dos grupos corais), afirma que só é possivel cantar em uníssono, de forma afinada, se, previamente, o cantor já for capaz de cantar, afinadamente, em duas partes:

[...] Eu cheguei à conclusão, quase incondicional, de que aqueles que podem cantar de forma afinada em uníssono são aqueles que já são capazes de cantar afinado em duas partes, anteriormente. Um "ré" só pode soar afinado quando soa contra o "sol" abaixo dele, formando uma quinta perfeita. Se um "ré" é cantado em seguida de um "dó", o ouvido interior deve oferecer o "sol" como suporte inferior para que ele soe afinado ${ }^{9}$ (Kodály, 1966 apud Kocsár, 2002, p. 39, tradução nossa) ${ }^{10}$.

Nesse sentido, o canto em partes pode se tornar conveniente e produtiva ferramenta para o desenvolvimento de habilidades musicais, tais como a própria afinação. No entanto, há formas de divisi que contribuem mais que outras nesse processo. Dwyer, em sua série de arranjos corais (apud Černý, 2009), indica uma sequência para desenvolver o canto em partes, ou com divisi. Para a maestrina, o passo preparatório é o uso de canções em uníssono,

\footnotetext{
9 É preciso inserir esta citação no contexto ocidental. Pode ser que a sensação de afinação provocada pelo intervalo de quinta justa, como exemplificado, não aconteça em outros contextos culturais.

10 "[...] I myself have come to the almost unconditional conclusion that only those can sing in tune in unison who have already been able to sing in tune in two parts before. A ' $D$ ' can only be in tune when it is sounded against the ' $G$ ' below in a perfect fifth. If a ' $D$ '”' is to be sung in tune after a ' $C$ ', the inner hearing must provide the supporting 'G' below in order for it to be in tune” (Kodály, 1966 apud Kocsár, 2002, p. 39).
} 
para que, em seguida, o coro introduza as seguintes formas de divisi: ostinato, descante, nota suspensa, cânone, entrada canônica, quodlibet, homofonia.

Dwyer observa que, ainda que estas formas de divisi estejam sequenciadas, há alguma flexibilidade em seu desenvolvimento, pois algumas delas trabalham habilidades semelhantes, como é o caso dos descantes e das notas suspensas (Dwyer apud Černý, 2009). Leck e Jordan (2009, p. 73), por exemplo, ao especificarem o repertório apropriado para cada nivel de habilidade coral, sugerem para os coros iniciantes que sejam trabalhadas canções em uníssono, com ostinatos a duas vozes, descantes e notas suspensas, nesta ordem. Já para o nivel iniciante-intermediário, os mesmos maestros indicam que sejam feitos, nesta ordem, cânones a duas e três vozes, quodlibets e homofonias.

Vale observar que, considerando os autores apontados acima, os cânones surgem, no repertório, em coros de nível mais avançado. Já o repertório dos corais iniciantes concentra canções com ostinatos, descantes e suspensões, o que sugere que estes formatos de divisi são mais fáceis de executar que os cânones. Assim, ao compor ou arranjar uma canção cujo objetivo seja introduzir o canto em partes, as formas indicadas acima são as que podem significar resultado satisfatório quando se pretende cantar em partes, ou em vozes, além de contribuir para o desenvolvimento musical dos cantores, na medida em que novos elementos são inseridos para o cumprimento de tal fim.

Quase todos os elementos que compõem esta sequência são marcados pela independência das vozes, em caráter horizontal, polifônico. Disso, podese observar que estas técnicas de desenvolvimento do canto em vozes seguem o caminho em que a polifonia (nas formas apontadas) antecede a homofonia, ou seja, as canções marcadas pela independência das vozes antecedem aquelas em que todas as vozes ou partes seguem no mesmo ritmo.

A fim de tornar mais claro o que foi dito acima, seguem abaixo alguns exemplos dessas formas de divisi.

\section{OSTINATO}

O ostinato é o nome dado à repetição de um padrão musical (Sadie, 1994). Existem ostinatos rítmicos, melódicos e harmônicos. Em trechos com divisão de vozes, os ostinatos melódicos facilitam este exercício por causa da independência atribuída às vozes e da repetição. Em geral, tem-se um grupo cantando o tema principal, enquanto pelo menos um dos outros se mantém no ostinato. Os exemplos abaixo indicam o tema principal (Figura 6), o ostinato melódico proposto no arranjo da canção em questão (Figura 7) e tema e ostinato juntos (Figura 8). Neste formato de divisi, nota-se com frequência a inversão de vozes. 
Tema:
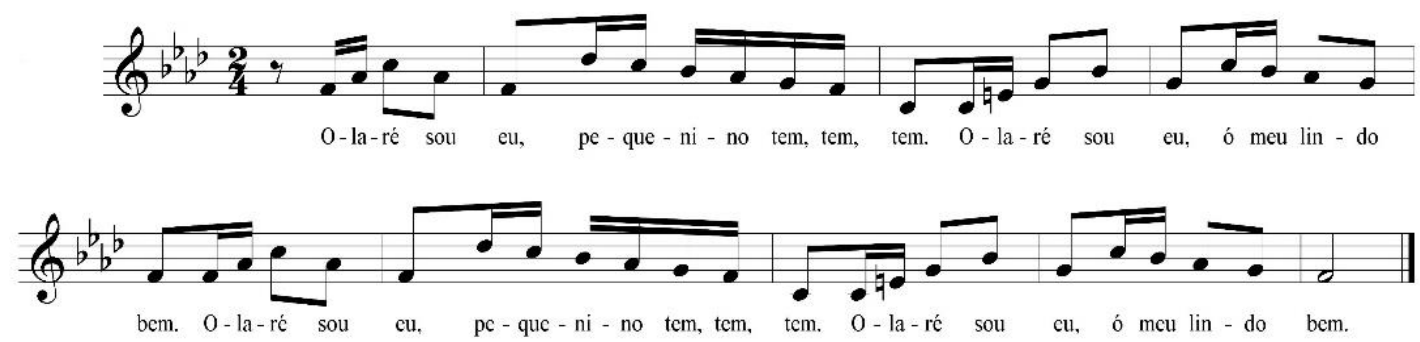

Figura 6: Tema da canção tradicional portuguesa "Olaré” (Fragoso, 2013).

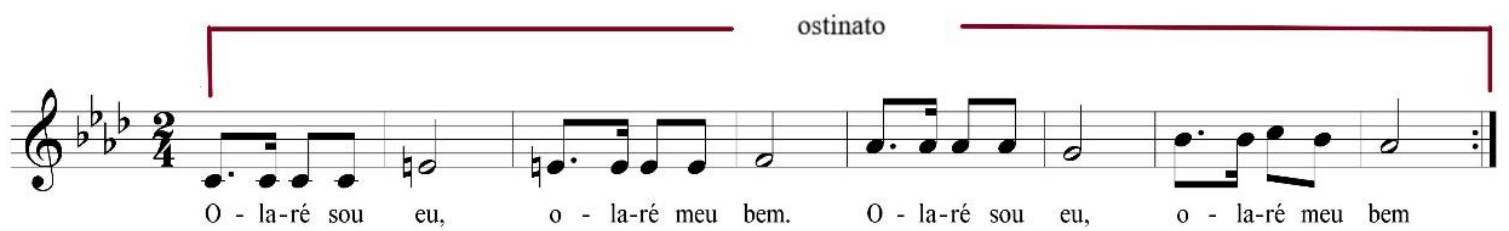

Figura 7: Ostinato elaborado no arranjo da canção tradicional portuguesa "Olaré” (Fragoso, 2013). 

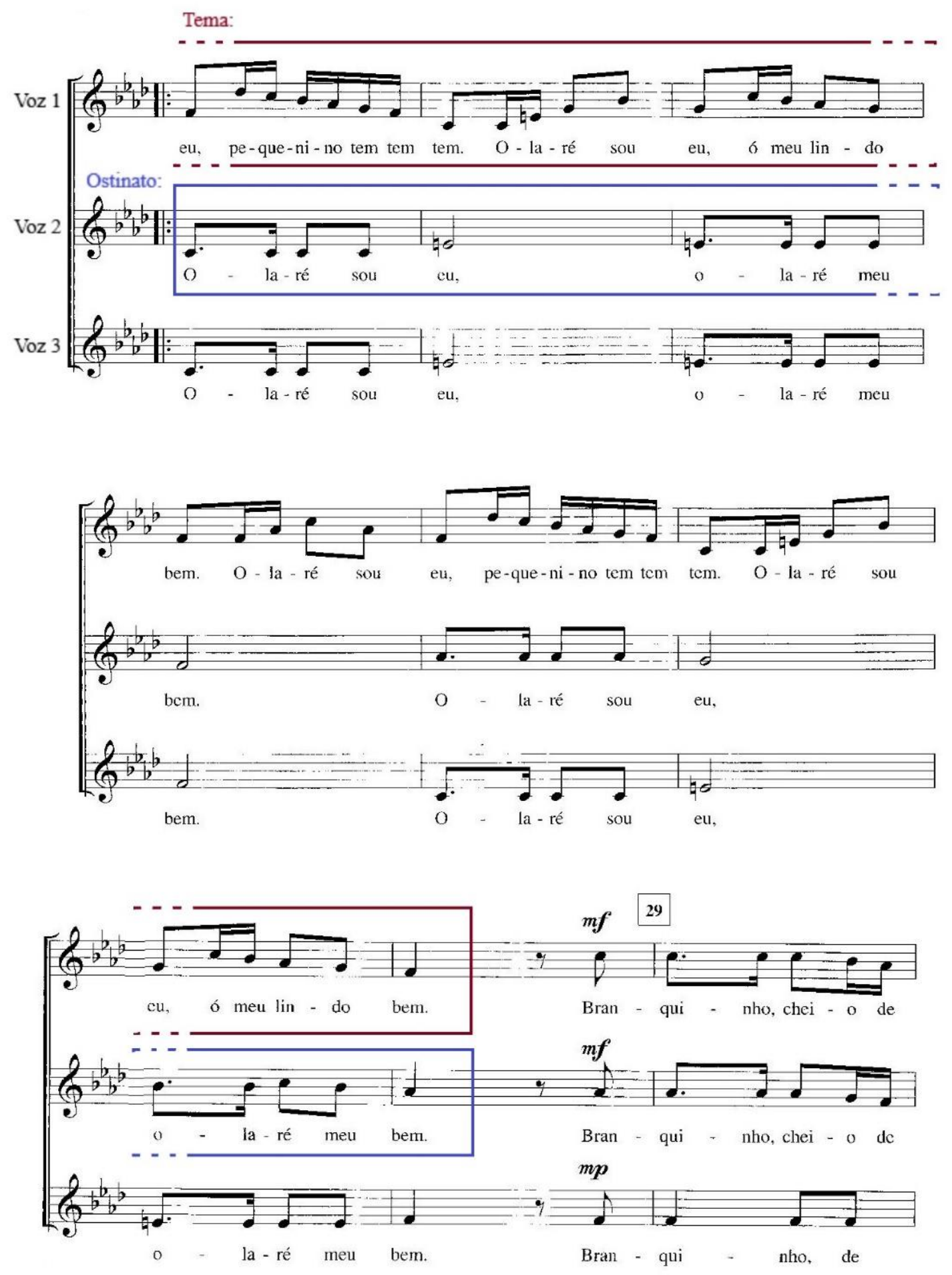

Figura 8: Trecho extraído da canção tradicional portuguesa "Olaré" (Fragoso, 2013), contendo tema e ostinato juntos.

\section{DESCANTE}

Um dos usos do termo "descante" refere-se a uma parte aguda, em geral, ornamentada, de alguma canção (Dicionário Grove de música, 1994). Normalmente, contrastam com o restante das partes e podem ser executadas pelo naipe todo, por um pequeno grupo ou pelo solista. 


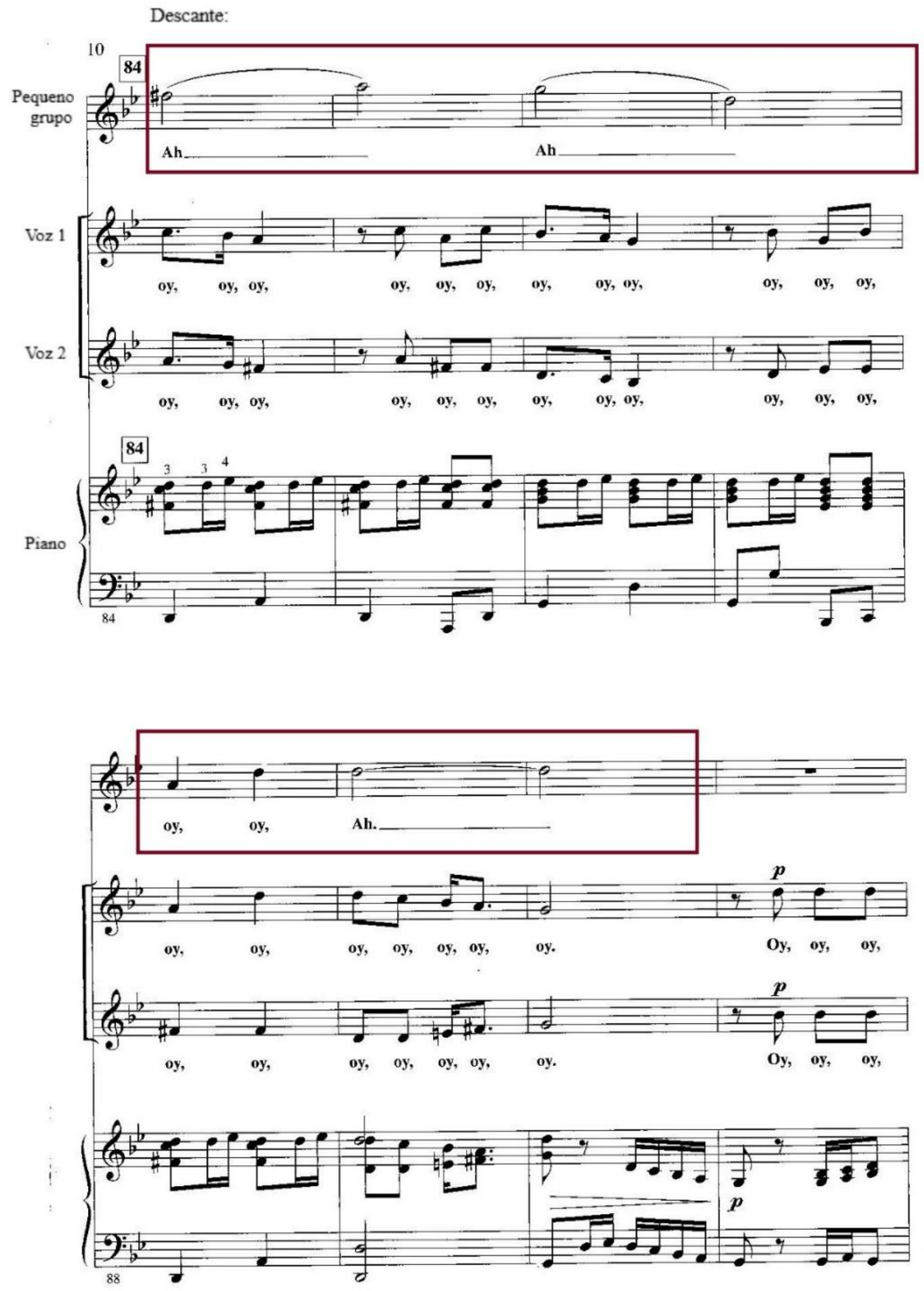

Figura 9: Descante de trecho extraído da canção tradicional judaica "Mir Zeinen Alle" (Leck; Ellis, 2007). 


\section{NOTA SUSPENSA}

As notas suspensas consistem no momento em que uma das partes sustenta a sua nota enquanto a(s) outra(s) seguem seu caminho. Em geral, ambas as vozes partem de uma nota comum, para que, então, a(s) seguinte(s) desenvolva(m) sua linha melódica.

No exemplo abaixo (Figura 10), destaca-se a nota suspensa na voz dos sopranos I, enquanto sopranos II e contraltos continuam seu trajeto (A). A parte indicada em (B) lembra uma nota suspensa no soprano II, porque ela se mantém nas palavras seguintes, enquanto as outras não, mas não é classificada como tal. A diferença de (A) para (B) é que este último pode ser mais dificil para o grupo executar, pois a partida de uma nota comum, precedendo o movimento em que uma voz segue e a outra repete sua nota, pode fazer com que o grupo encarregado da parte formada pelas notas repetidas tente acompanhar o grupo que prosseguiu. O motivo para tal pode consistir no fato de que, em (B), as vozes não soam tão independentemente, como em (A). 

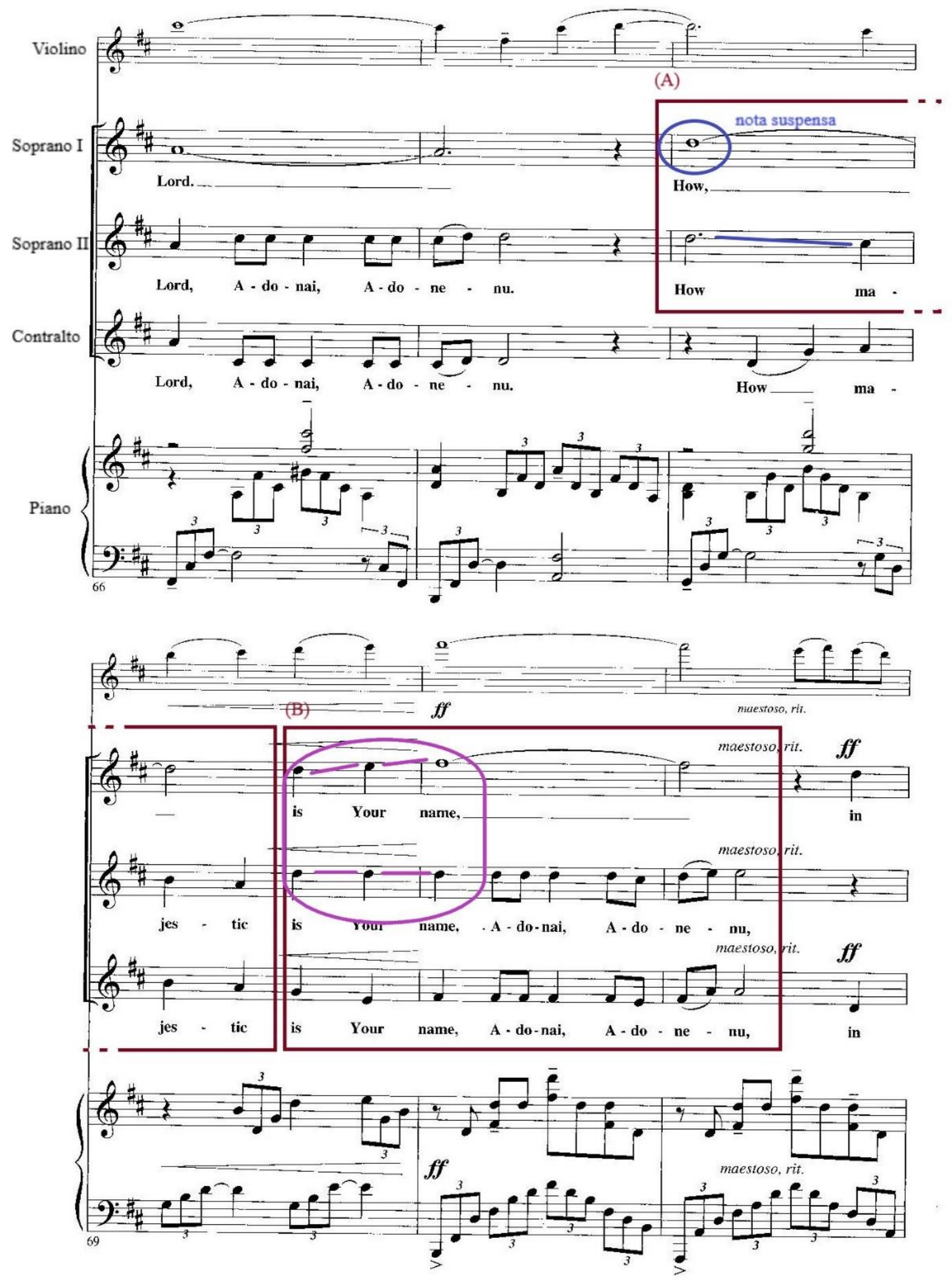

Figura 10: Trecho contendo nota suspensa, extraído da obra "Psalm 8" (Forrest, 2010). 


\section{CÂNONE}

Os cânones são imitações contrapostísticas rigorosas da melodia principal, de modo que, ao soarem juntas as partes, é explicitada a harmonia da música. A entrada de cada grupo é indicada por números ou letras, de modo que o primeiro grupo inicia a música no número (1) ou na letra (A); o segundo inicia a música quando o primeiro alcançar o número (2) ou a letra (B); o terceiro, quando o primeiro alcançar a indicação (3) ou (C); e assim por diante. Foram escolhidos dois exemplos para esta forma: o primeiro é de uma canção tradicional eslovaca, com texto em húngaro (Figura 11) - "Egy boszorka van" ("Uma bruxa", ou "Era uma vez uma bruxa"). Esta canção faz parte de um dos livros didáticos utilizados por algumas escolas húngaras nas aulas de música para o $2^{\circ}$ ano (Szabó, 1992, p. 33).

Já o exemplo seguinte é um cânone a quatro vozes iguais composto pelo húngaro György Ligeti, em 1952 (Figura 12), e com texto de Sándor Weöes. Apesar de o título "Pletykázó asszonyok" (que pode ser traduzido por "Mulheres fofoqueiras") reforçar estereótipos de gênero, pode-se observar a relação proposta na composição entre sua forma canônica e o resultado harmônico e o texto (que se refere às fofocas das tias Juli e Káti, sentadas na esquina) ${ }^{11}$. Vale chamar a atenção para a inversão de vozes ocorrentes nos exemplos dados e nesta forma de divisi.

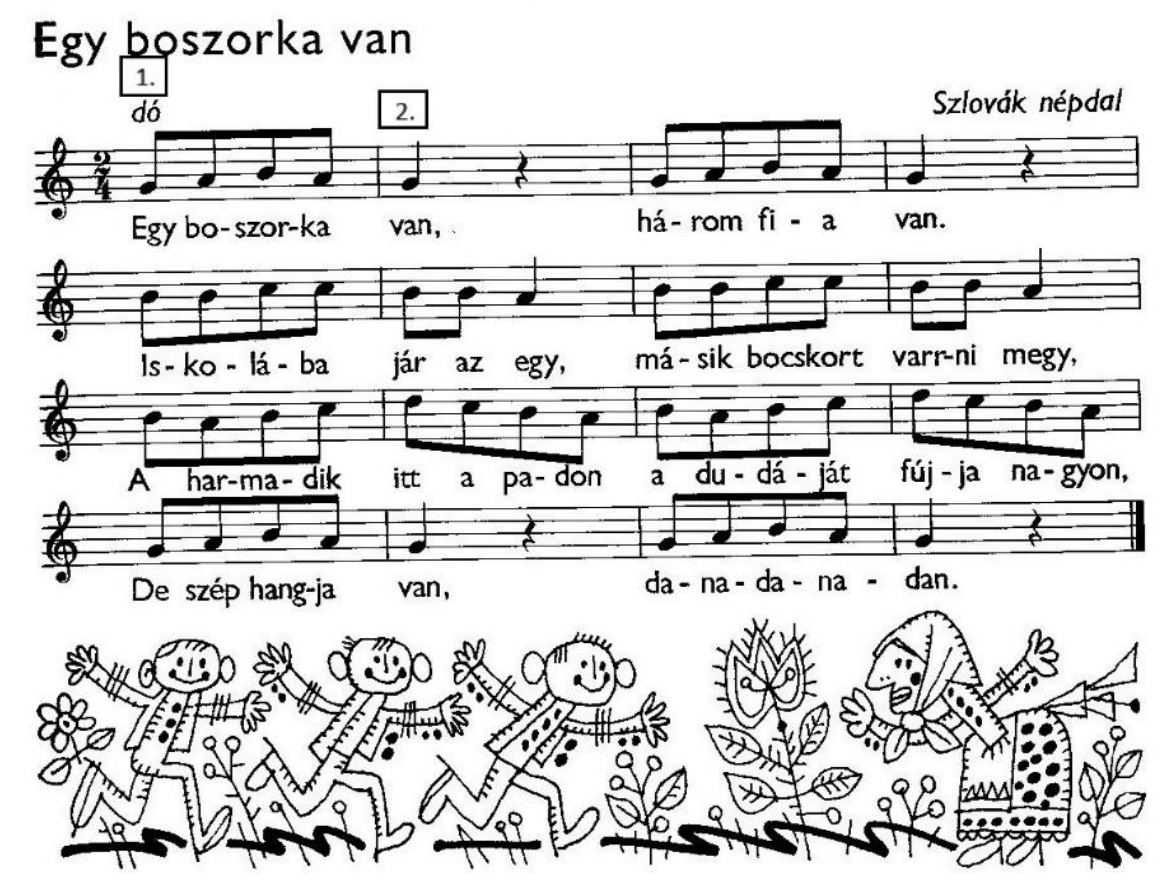

Figura 11: Cânone a duas vozes da canção tradicional eslovaca "Egy boszorka van". Imagem extraída do livro de autoria de Szabó (1992).

${ }^{11}$ Vertamatti (2008, p. 126-129) traz uma análise bem oportuna da obra, incluindo a tradução do texto. 


\section{Pletykázó Asszonyok}
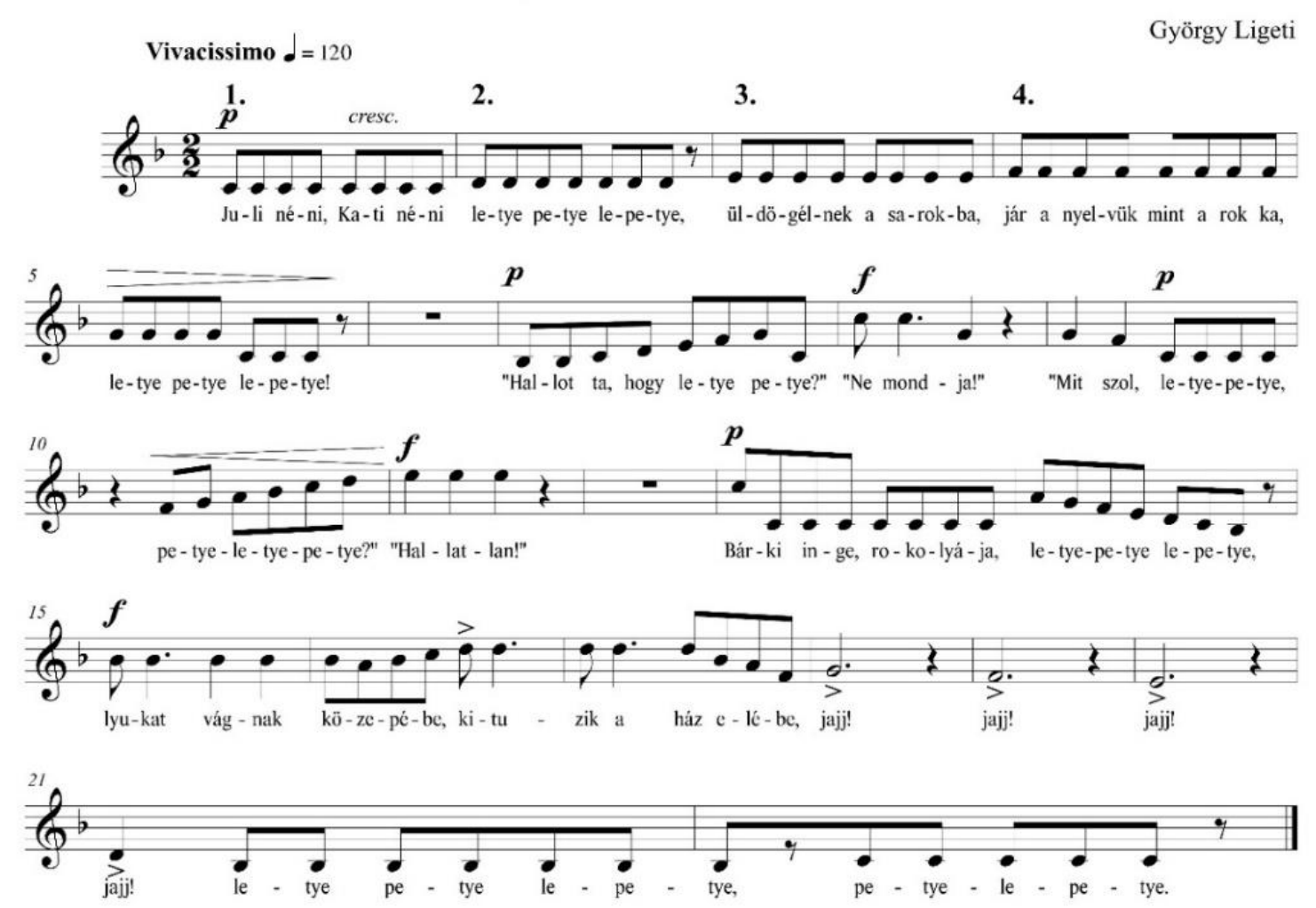

Figura 12: "Pletykázó asszonyok", cânone a quatro vozes, de G. Ligeti12, composta em 1952 e publicada em 1988.

\section{ENTRADA CANÔNICA}

As entradas canônicas são pequenas entradas em forma de contraponto. Mais uma vez, são caminhos oportunos para se trabalhar o divisi com os coralistas, pois, de fácil execução, soam como se fossem ecos da linha principal. Aqui também são comuns as inversões de vozes.

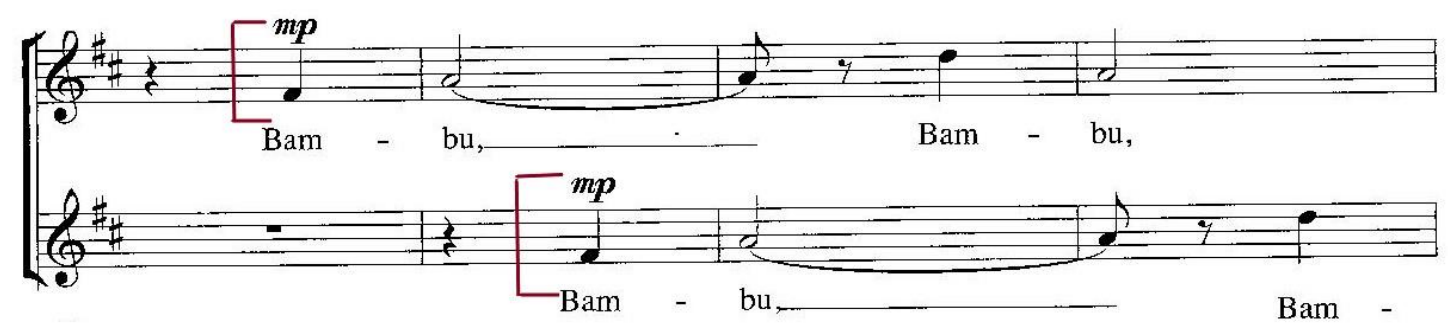

Figura 13: Trecho extraído da canção "Bambu” (Dwyer; Castro, 2016).

12 Transcrição nossa, baseada na partitura utilizada por Vertamatti (2008, p. 126). 


\section{QUODLIBET}

Os quodlibet reúnem, em uma só canção, temas ou trechos melódicos (ou mesmo melodias inteiras) de canções distintas e independentes superpostos, mas que se correspondem em relação à sua estrutura harmônica. No cancioneiro brasileiro infantil, um dos quodlibet mais conhecidos é "Bão balalão"13 com "Lua, luar"14. Além deste, Loureiro e Tatit (2014) também propõem alguns quodlibet a partir do repertório tradicional brasileiro e português.

O exemplo abaixo ilustra um quodlibet arranjado para 3 vozes iguais por Dwyer e Waller (1994). A Figura 17 apresenta a superposição dos três temas (discrimados nas Figuras 14 a 16) propostos pelos arranjadores.

Tema A:
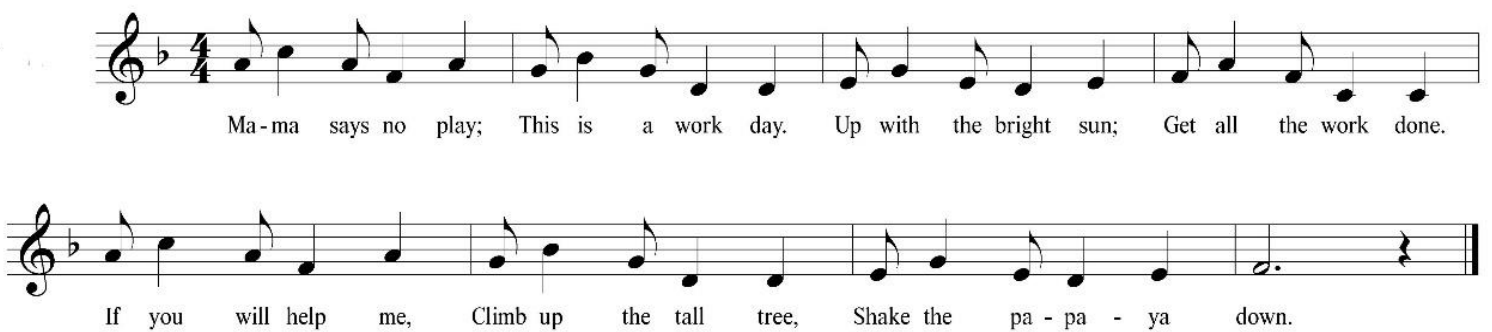

Figura 14: Tema 1 da canção "Shake the Papaya Down" (Dwyer; Waller, 1994).

Tema B:
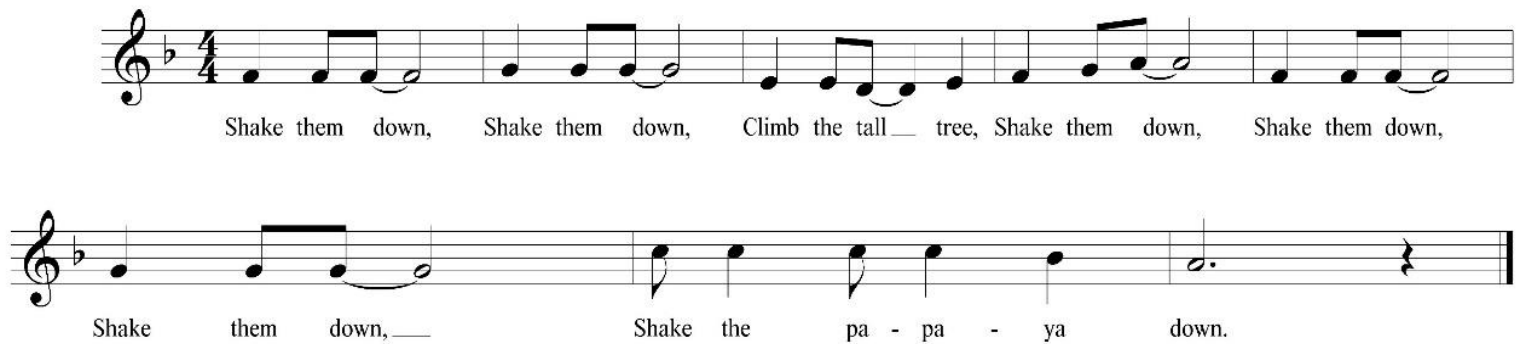

Figura 15: Tema 2 da canção "Shake the Papaya Down" (Dwyer; Waller, 1994).

13 Ou "Bam-ba-la-lão".

14 Ou "Oferta da criança à lua". 
Tema C:
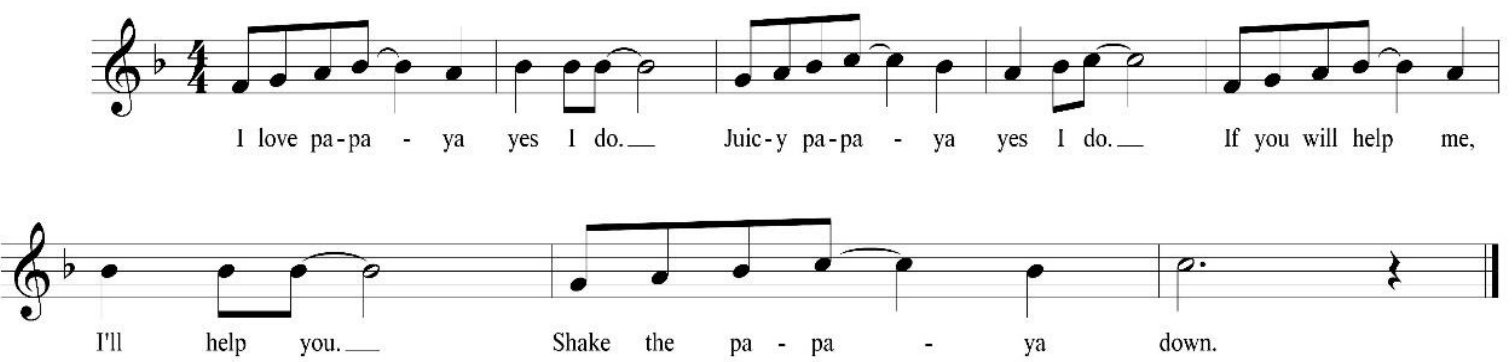

Figura 16: Tema 1 da canção "Shake the Papaya Down” (Dwyer; Waller, 1994).
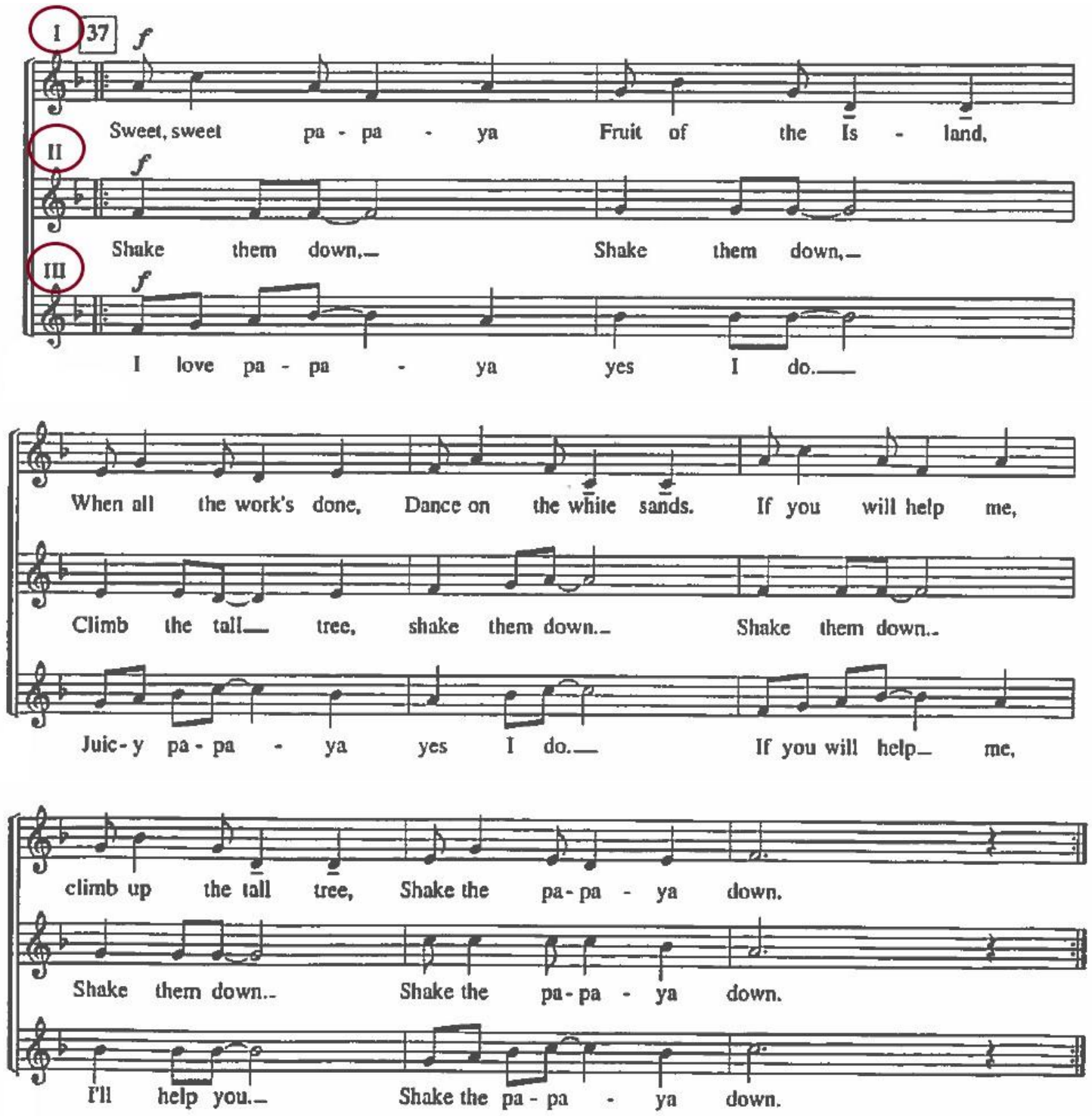

Figura 17. Temas 1, 2 e 3 da canção "Shake the Papaya Down" escritos simultaneamente, em quodlibet (Dwyer; Waller, 1994). 


\section{HOMOFONIA}

Na sequência estabelecida por Dwyer (apud ČERNÝ, 2009) e Leck e Jordan (2009), a homofonia é o último passo do desenvolvimento do canto em partes. Essa colocação se justifica no fato, já apontado acima, de que as linhas de cada voz não são independentes, como mostra a Figura 18. Sugere-se neste artigo que trechos homofônicos sejam introduzidos sutilmente, e um dos caminhos para tal é começar o divisi por grau conjunto (Figura 19), e, se possivel, em movimentos contrários, isto é, se uma voz está subindo, a outra deve descer. Os movimentos paralelos, em que as notas fazem o mesmo desenho ou movimento, pelo que tenho visto, são os mais dificeis de se precisar, porque os cantores tendem a transitar entre uma voz e outra. Ainda assim, desejando incluir movimentos paralelos nos arranjos, os intervalos de quinta ou quarta, em geral, fluem bem.

Vale lembrar que estas são observações gerais e que, sem dúvida, serão encontrados coros infantis ou crianças que terão mais ou menos facilidade para cantar estes intervalos (e mesmo as formas de divisi propostas acima). No Brasil, por exemplo, onde são muito comuns canções em terças, ou seja, canções em que a melodia principal é acompanhada de terças superiores ou inferiores, pode ser que os cantores tenham um desempenho satisfatório em relação a essa forma de divisão que, em princípio, é de difícil execução por conta do paralelismo; enquanto que, para essa população, pode ser desafiante cantar em quartas, já que o ouvido pode não estar culturalmente acostumado a essa sonoridade. Por esta razão, reforça-se a necessidade de o arranjador conhecer o grupo para o qual escreve, a fim de valorizar o que é bem executado e de propor desafios em medida apropriada para o desenvolvimento musical do coro. 


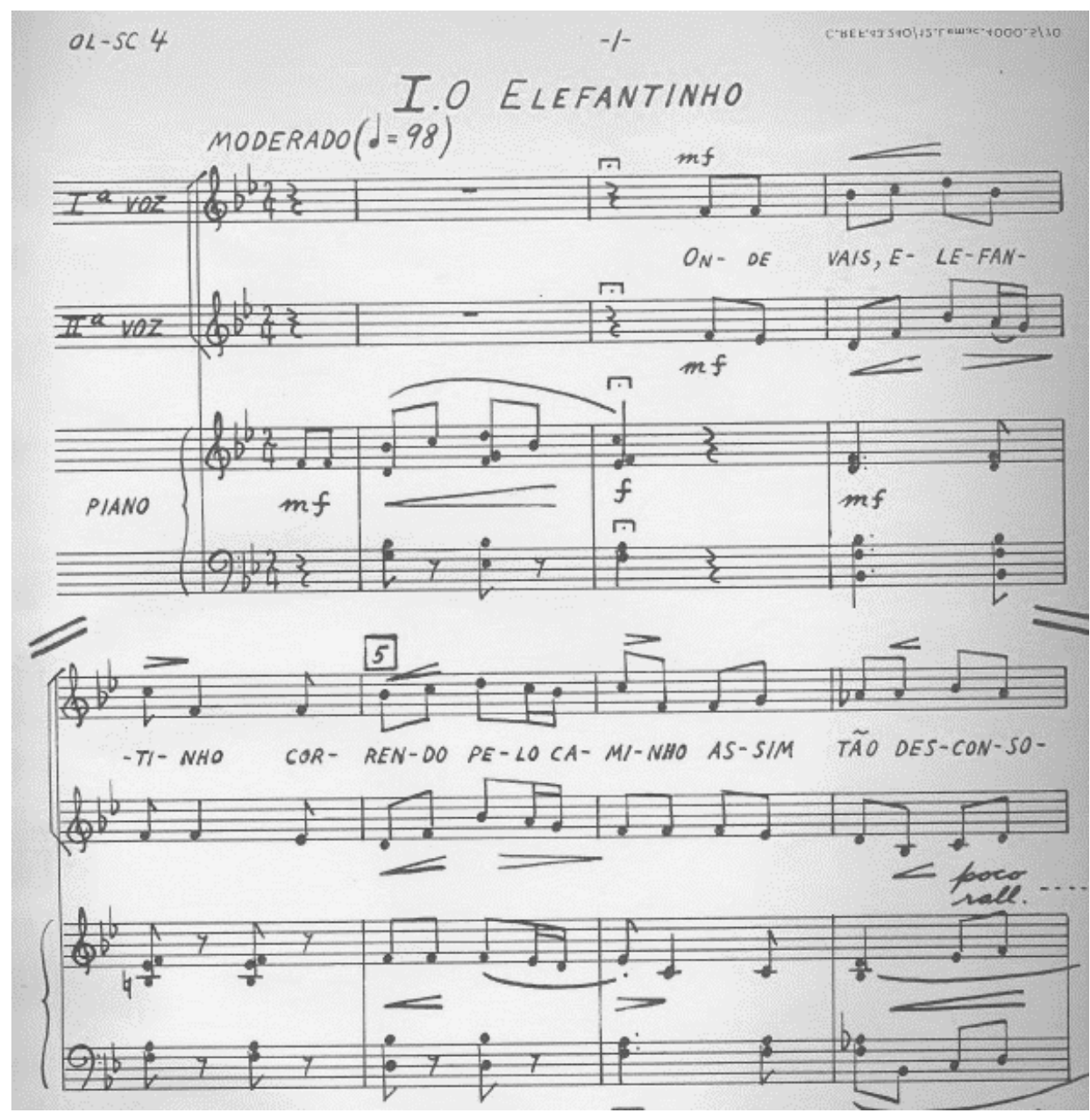

Figura 18: Trecho do primeiro movimento - "O elefantinho", com letra de Vinícius de Moraes - da Suíte coral nº para coro infantil ou coro juvenil a duas vozes e piano, de Osvaldo Lacerda.

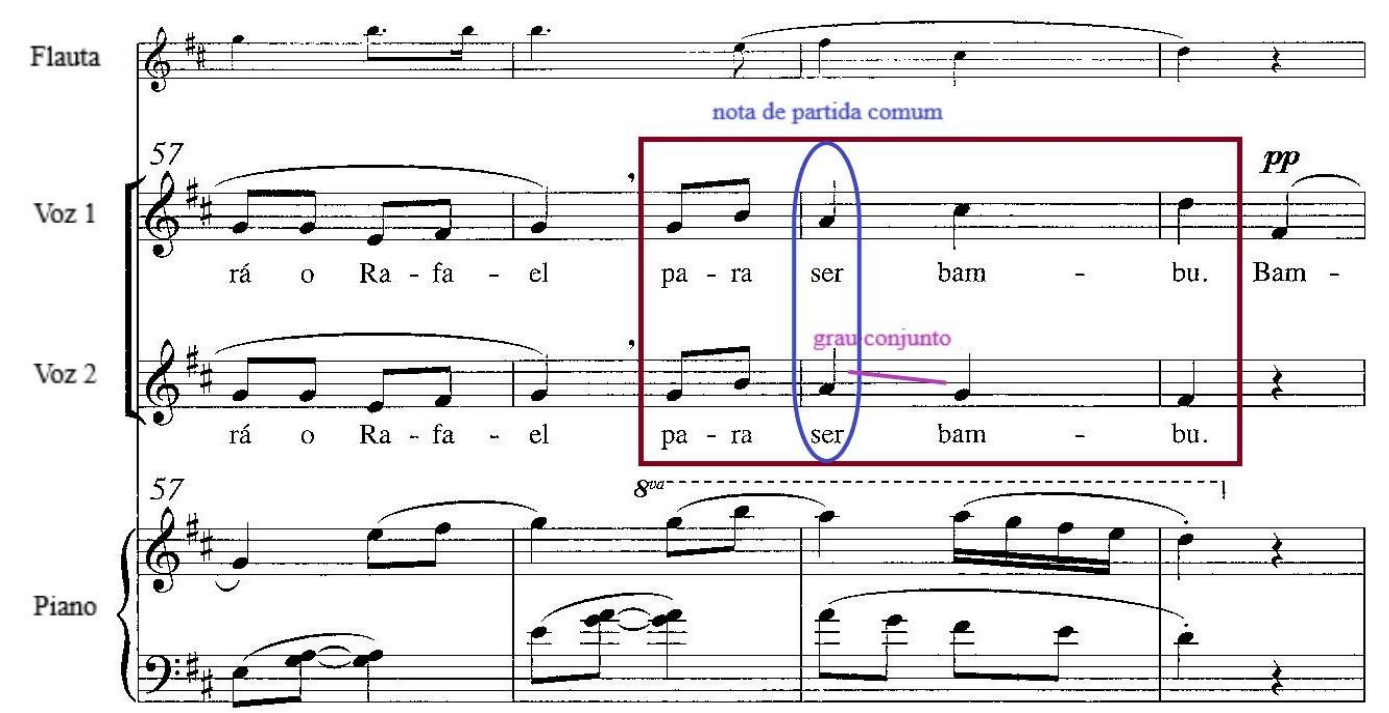

Figura 19. Trecho da canção tradicional brasileira "Bambu" (Dwyer; Castro, 2016). 


\section{CONSIDERAÇÕES FINAIS}

A elaboração de arranjos é um dos territórios da criação. Com frequência, os arranjos são escritos a partir de experimentações e improvisações do arranjador, que vão se ajustando até ganhar forma definida. Se a escassez de material para coro infantil tem sido motivo para que músicos de diversas áreas tenham se colocado como arranjadores para esta formação, sugere-se aqui que a criação de arranjos e mesmo composições musicais se efetivem por outra via: pela assunção da autonomia suficiente para criar, para compor, e pelo próprio ato de criar. Além disso, quantos mais se lançarem nesta tarefa, mais chance temos de encontrar material que se adéque ao coro que conduzimos, afinal, em se tratando de grupos e indivíduos pertencentes a contextos específicos, singulares, com necessidades socioculturais e musicais igualmente específicas e singulares, carecemos de arranjos que atendam a essa demanda, que, ao reunir tais singularidades, é tão plural.

As ferramentas aqui oferecidas são sugestões que partiram do que se tem feito em alguns lugares e influenciadas pela minha trajetória na educação musical e no canto coral infantil. Haverá, provavelmente, ferramentas outras que se adequarão melhor a um grupo específico, que não as listadas. Por isso a necessidade de regentes-criadores, de pianistas-criadores, de coralistascriadores, enfim, de criadores: para responder às necessidades dos polos onde cada um destes está inserido.

Enquanto meio de educação musical, o canto coral é mais um espaço favorável para o desenvolvimento social, cultural e musical dos indivíduos que estão inseridos nessa forma de fazer música. Como prática coletiva, todos os que estão nela envolvidos são convidados a criar: que os regentes se sintam convidados à criação; que os instrumentistas acompanhadores se sintam convidados à criação; que os coralistas (em quaisquer idades) sejam convidados à criação.

\section{REFERENCIAS}

BOECHAT, B.; SILVEIRA, S. Ajudando a criança a encontrar sua voz cantada. In: SOBREIRA, S. (Org.). Se você disser que eu desafino... Rio de Janeiro: UNIRIO: Instituto Villa-Lobos, 2017.

BRAGA, Simone; TOURINHO, Cristina. Um por todos ou todos por um? Processos avaliativos em música. Feira de Santana, BA: UEFS, 2013.

BRITO, M. T. A. Hans-Joachim Koelrreutter: ideias de mundo, de música, de educação. São Paulo: Peirópolis, 2015.

BRITO, M. T. A. Por uma educação musical do pensamento: novas estratégias de comunicação. Tese (Doutorado) - Pontifícia Universidade Católica de São Paulo, São Paulo, 2007. 
CARNASSALE, G. J. O ensino de canto para crianças e adolescentes. Dissertação (Mestrado) - Instituto de Artes, Universidade Estadual de Campinas, Campinas, 1995.

ČERNÝ, L. Ej, lásko, lásko. Arranjo para duas vozes iguais, flauta doce, violoncelo e piano. Indianapolis: Colla Voce Music, 2009.

COOPER, S. Ah, poor bird. Arranjo para duas vozes iguais e piano. Wisconsin: Hal Leonard Corporation, 2009.

SADIE, Stanley (Ed.). Dicionário Grove de Música: edição concisa. Rio de Janeiro: Jorge Zahar Ed., 1994

DWYER, R.; CASTRO, P. Bambu. Arranjo para duas vozes iguais, piano e flauta. Indianapolis: Colla Voce Music, 2016.

EMERSON, R. Blue skies. Arranjo para duas vozes iguais e piano. Wisconsin: Hal Leonard Corporation, 2001.

FORREST, D. Psalm 8. Composição para coro SSA, piano, violino e percussão. Wisconsin: Hal Leonard Corporation, 2010.

FRAGOSO, D. De prosa com o passarim. Arranjo para três vozes iguais, piano e percussão. Wisconsin: Hal Leonard Corporation, 2013.

FRAGOSO, D. Entre a opy e a sala de aula: arranjos entre crianças guarani Mbya e crianças não indígenas. 2015. Dissertação (Mestrado) - Escola de Comunicações e Artes, Universidade de São Paulo, São Paulo, 2015.

FRAGOSO, D. Olaré. Arranjo para duas vozes iguais, piano, flauta e percussão. Wisconsin: Hal Leonard Corporation, 2017.

FREIRE, P. Pedagogia da autonomia: saberes necessários à prática educativa. São Paulo: Paz e Terra, 1996.

GABORIM-MOREIRA, A. L. I. Regência coral infantojuvenil no contexto de extensão universitária: a experiência do PSIU. Tese (Doutorado) - Escola de Comunicações e Artes, Universidade de São Paulo, São Paulo, 2015.

GAINZA, Violeta Hemsy de. La Iniciación Musical del Niño. Buenos Aires: Ricordi Americana, Sociedade Americana e Editorial, 1964.

GREEN, B. Cirandeiro (Join the Dance). Arranjo para duas vozes iguais e piano. Wisconsin: Hal Leonard Corporation, 2005.

HEDDEN, D. An overview of existing research about children's singing and the implications for teaching children to sing. National Association for Music Education, Virginia, v. 30, n. 2, p. 52-63, 2012. 
JOLY, M. C. L.; JOLY, I. Z. L. Práticas musicais coletivas: um olhar para a convivência em uma orquestra comunitária. Revista da $A B E M$, Londrina, v. 19, n. 26, p. 79-91, jul./dez. 2011.

JOLY, I. Z. L.; SEVERINO, N. B (Orgs.). Processos educativos e práticas sociais em música: um olhar para educação humanizadora: pesquisas em educação musical. Curitiba: CRV, 2016.

KIM, Jinyoung. Children's pitch matching, vocal range and developmentally appropriate practice. Journal of Research in Childhood Education, v. 12, n. 2, p. 152-160, 2000.

KOCSÁR, I. H. (compilação). Zoltán Kodály: music should belong to everyone: 120 quotations from Kodály's writings and speeches. National Cultural Foundation: Budapeste, 2002.

LEAL, E. R. F. O acompanhamento ao piano para coro infantil. Dissertação (Mestrado) - Instituo de Artes, Universidade Estadual de Campinas, Campinas, 2005.

LECK, H; ELLIS, M. Mir zeinen alle (ale brider). Arranjo para duas vozes iguais e piano. Wisconsin: Hal Leonard Corporation, 2007.

LECK, Henry; JORDAN, Flossie. Creating artistry through choral excellence. Milwaukee, WI: 2009.

LOUREIRO, M.; TATIT, A. Desafios musicais. São Paulo: Melhoramentos, 2014.

MOORE, R. S. Comparison of children's and adults' vocal ranges and preferred tessituras in singing familiar songs. Bulletin of the Council for Research in Music Education, v. 107, p. 13-22, 1991.

PFAUTSCH, Lloyd. The choral conductor and the rehearsal. In: DECKER, Harold A.; HERFORD, Julius (Orgs.). Choral conducting symposium. [S.1.]: Pearson College Division, 1988.

ROBINSON, Ray; WINOLD, Allen. The choral experience: literature, materials, and methods. [S.1.]: Harper's College Press, 1976.

SANTOS, R. M. S. Cartografias na educação infantil: quem joga? In: ENCONTRO ANUAL DA ASSOCIAÇÃO BRASILEIRA DE EDUCAÇÃO MUSICAL, .9, 2000, Belém. Anais... Belém: Abem, 2000. p. 111-131.

SZABÓ, H. Énekeskönyv 2: emelt szintű tankönyv az általános iskola 2. osztálya számára. Nemzeti Tankönyvkiadó: Budapeste, 1992.

TARGAS, K. M.; JOLY, I. Z. L. Canções, diálogos e educação: uma experiência em busca de uma prática escolar humanizadora. Revista da $A B E M$, Porto Alegre, v. 21, p. 113-123, mar. 2009. 
UTSUNOMIYA, M. M. O regente de coro infantil de projetos sociais $e$ as demandas por novas competências e habilidades. Dissertação (Mestrado) Escola de Comunicações e Artes, Universidade de São Paulo, São Paulo, 2011.

VERTAMATTI, L. R. G. Ampliando o repertório do coro infanto-juvenil: um estudo inserido em uma nova estética. São Paulo: Editora UNESP; Rio de Janeiro: Funarte, 2008.

Daisy Fragoso é Doutoranda e Mestra em Musicologia (com linha de pesquisa em Etnomusicologia) pela ECA-USP. Educadora musical formada em Licenciatura em Música pela mesma instituição e professora de música na educação básica. 